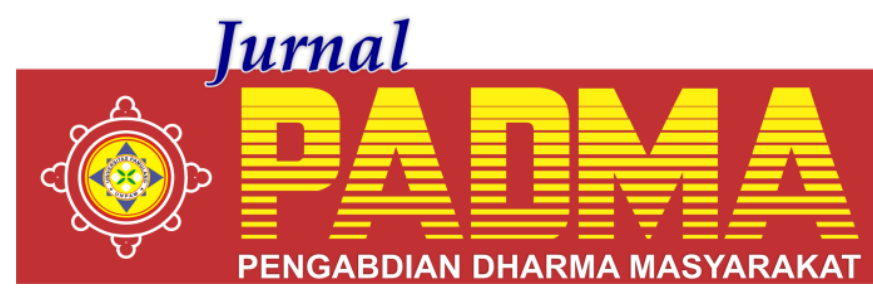

\title{
PEMULIHAN KEUANGAN KELUARGA KETIKA PANDEMI COVID-19 MELALUI PELATIHAN PERSONAL FINANCIAL HEALTH CHECK UP
}

\author{
${ }^{1 *}$ Dede Hertina, , ${ }^{2}$ S Susanto Hendiarto, ${ }^{3}$ John Henry Wijaya \\ Universitas Widyatama, Bandung, Jawa Barat, Indonesia \\ *dede.hertina@widyatama.ac.id
}

\begin{abstract}
Abstrak
Selama pandemi coronavirus disease (COVID-19) bisnis Usaha Mikro Kecil dan Menengah (UMKM) di Indonesia mengalami penurunan tajam. Hal itu disebabkan oleh kebijakan pengendalian COVID-19 yang membuat operasional UMKM menjadi terganggu. Dampaknya, banyak UMKM yang mengalami penurunan pedapatan. Kondisi tersebut harus ditanggulangi oleh UMKM agar tetap bertahan. Tujuan dari penelitian ini adalah untuk melakukan pemulihan keuangan keluarga ketika pandemi Covid-19 Melalui Pelatihan Personal Financial Health Check Up. Adapun yang menjadi target kegiatan adalah UMKM yang terdampak COVID-19 binaan Kadin Jawa Barat. Metode yang digunakan dalam pengabdian ini adalah sosialisasi interaktif dengan pemaparan strategi-strategi untuk mempertahankan UMKM dan melakukan tanya jawab melalui kegiatan Webinar.
\end{abstract}

Kata Kunci : Financial Health Check Up

\section{Abstract}

During the coronavirus disease (COVID-19) pandemic, Micro, Small and Medium Enterprises (UMKM) businesses in Indonesia experienced a sharp decline. This was due to the COVID-19 control policy which disrupted UMKM operations. As a result, many UMKM have experienced a decline in income. These conditions must be overcome by UMKM in order to survive. The purpose of this study is to recover family finances during the Covid-19 pandemic through Personal Financial Health Check Up training. As for the target of the activity are UMKM affected by COVID-19 assisted by the West Java Chamber of Commerce and Industry. The method used in this service is interactive socialization with the presentation of strategies for maintaining UMKM and conducting questions and answers through webinars.

Keywords: Financial Health Check Up.

\section{PENDAHULUAN}

Pandemi Covid-19 memberikan dampak besar di dunia. Maffioli (2020) menyatakan tingkat kecepatan dan cakupan penyebaran virus ini melebihi kejadian kasus lainnya. Respon masyarakat dalam menghadapi pandemi ini pun sangat berbeda dan dampak yang dirasakan sangatlah besar. Berdasarkan laporan Organization for Economic Co-operation and Development (OECD) dikatakan bahwa pandemi ini akan memberikan ancaman krisis ekonomi besar berupa penurunan aktivitas produksi, merosotnya tingkat konsumsi dan kepercayaan konsumen, hingga penurunan drastis bursa saham.

Khan (2020) dalam penelitiannya terhadap perekonomian China menyatakan bahwa terjadinya penurunan angka pertumbuhan perekonomian dari 6 persen menjadi 2 persen pada sebelum terjadinya Covid-19. McKibbin \& Vines (2020) serta McKibbin \& Fernando (2020) menyatakan pada penelitiannya bahwa wabah Covid-19 menunjukkan dampak pada ekonomi global secara signifikan. Maijamaa (2020) menyatakan penyebaran Covid-19 tidak hanya akan berdampak bagi negara China saja, tetapi juga akan lebih meluas hingga mendunia dikarenakan peran China dalam sektor ekonomi dunia yang kuat. Indonesia sebagai negara berkembang juga mengalami dampak atas pandemic Covid-19 ini. Merujuk pada Amri (2020), dampak tersebut memberikan efek yang sangat besar terhadap berbagai sektor. Menurut Data Resmi Statistik No. 39/05/Th. XXIII, 5 Mei 
2020, besaran PDB triwulan I tahun 2020 mengalami penurunan pertumbuhan ekonomi dari 5,07 persen (tahun 2019) menjadi 2,97 persen. Badan Kebijakan Fiskal (BKF) Kementerian Keuangan memperkirakan angka kerugian hingga Rp320 triliun pada Triwulan I tahun 2020 akibat pandemi. Hal ini disebabkan ekonomi nasional merosot sekitar 2,03 persen, yang memberikan dampak besar dan akan mengancam perekonomian Indonesia, jika hal ini tidak ditangani secara serius. Pemerintah dalam mengatasi pandemi dimulai dengan memberlakukan Pembatasan Sosial Berskala Besar (PSBB) atau social distancing sejak awal Maret 2020.

Peraturan ini memiliki efek nyata pada masyarakat dimana aktivitas sehari-hari menjadi terhambat sehingga masyarakat dituntut untuk melakukan setiap kegiatan dari rumah dan digitalisasi dalam setiap kegiatan sehari- hari seperti Work From Home (WFH) hingga belajar secara daring. Hadiwardoyo (2020) menyatakan kebijakan PSBB ini harus dilakukan dengan pertimbangan tepat dan benar, hal ini disebabkan dengan pembatasan yang berkepanjangan dapat berisiko besar terkait kemampuan individu dalam menjalankan kehidupannya. Kebijakan ini memberikan dampak penurunan drastis perekonomian Indonesia akibat berhentinya sektor industri pariwisata dan penurunan di sektor manufaktur. Berdasarkan data Badan Pusat Statistik (BPS) Kementerian Koperasi dan Usaha Kecil Menengah (Kemenkop UKM, 2018), Usaha Mikro, Kecil dan Menengah (UMKM) adalah pelaku utama yang mendominasi perekonomian Indonesia. Hal ini terjadi pada saat krisis ekonomi yang melanda Indonesia tahun 1997-1998. Menurut Sarfiah (2019), UMKM sebagai pahlawan atau penopang perekonomian Indonesia, terlihat dari jumlahnya yang terus meningkat pasca krisis tersebut. Sebanyak 64,2 juta UMKM di Indonesia (99 persen dari total unit usaha) tercatat pada tahun 2018 dan memiliki tenaga kerja sebanyak 116,98 juta orang ( 97 persen dari total tenaga kerja di sektor ekonomi) Sebanyak 60 persen Produk Domestik Bruto Indonesia berasal dari UMKM. Hal ini menyatakan bahwa UMKM berperan penting dalam menjaga perekonomian dalam negeri. Merujuk pada Amri (2020), pandemi Covid-19 dapat memberikan ancaman dan juga peluang bagi para pengusaha. Ancaman tersebut terlihat yaitu tidak sedikit UMKM yang mengalami kesulitan keuangan bahkan tidak sedikit yang mengalami penutupan usaha. Penurunan omzet hingga tidak ada pemasukan sama sekali dan terpaksa gulung tikar diakibatkan yang diakibatkan adanya kebijakan PSBB. Oleh karena itu, dalam menanggulangi terjadinya hal yang tidak diinginkan, UMKM harus mampu mengambil peluang lain dalam menghadapi pandemi ini. UMKM harus mampu bersaing dalam mempertahankan eksistensinya di tengah masalah global ini. Perkembangan dan pertumbuhan UMKM harus ditingkatkan dan diberikan perhatian secara intensif oleh pemerintah. Kebijakan PSBB mengharuskan mayoritas kegiatan dilakukan di rumah atau Work From Home (WFH). Kondisi ini dapat dijadikan pembelajaran bagi para pemilik bisnis untuk beradaptasi dalam menghadapi pandemi. Bagi UMKM hal ini penting untuk dihadapi. Salah satunya, penting untuk mengimplementasikan digitalisasi pada setiap kegiatan jual beli dan interaksi lainnya. Kemampuan teknologi dan inovasi serta kreativitas diperlukan dalam membaca peluang yang ada seperti dalam aspek permodalan usaha, strategi manajemen, strategi promosi dan pemasaran, serta strategi finansial. Peran pemerintah juga diperlukan dalam mendorong keberhasilan UMKM dari segi alokasi perizinan hingga pembiayaan atau permodalan begitupun pelatihan tenaga kerja. Atas dasar kondisi UMKM pada masa pandemic seperti dipaparkan di ata, dalam makalah ini disajikan hasil pengumpulan data dan 
pemetaan mengenai gambaran profil usaha sehingga dapat dilihat dan dipelajari lebih lanjut aspek-aspek terkait kelayakan usaha pada masa pandemi ini supaya menjadi pertimbangan dalam melakukan upayaupaya untuk memperkuat UMKM. Berdasarkan data yang diperoleh diarahkan upaya Pemulihan Keuangan Keluarga Ketika Pandemi Covid-19 Melalui Pelatihan Personal Financial Health Check Up melalui kegiatan Webinar Pengabdian Pada Masyarakat yang diselenggarakan pada hari Kamis tanggal 25 Februari 2021 atas kerjasama antara Dosen Fakultas Ekonomi dan Bisnis Universitas Widyatama dengan Kadin Jawa Barat.

\section{METODE}

Metode kegiatan yang digunakan pada artikel Pengabdian Kepada Masyarakat ini diharapkan dapat memulihkan keuangan keluarga ketika pandemi covid-19 melalui pelatihan Personal Financial Health Check Up. Pelaku UMKM binaan Kadin Jawa Barat sebanyak 33 mitra binaan dari jenis yang berbeda ini sebagian besar atau 90 persennya adalah wanita dan mitra lainnya laki-laki.

Dalam kegiatan ini, metode yang digunakan adalah penjelasan (pemaparan), diskusi dan tanya jawab melalui zoom webinar. Kegiatan melalui Zoom webinar dipilih untuk mendukung upaya pemerintah memutus rantai penyebaran virus corona (Covid-19) dengan melaksanakan physical distancing. Dengan bentuk kegiatan ini pihak perguruan tinggi tetap dapat produktif dan berbagi pengetahuan kepada masyarakat, terutama pelaku UMKM binaan Kadin Jawa Barat. Webinar ini mentargetkan para pelaku UMKM yang terkena dampak pandemi Covid19, agar mampu melakukan upaya pemulihan keuangan keluarga ketika pandemi Covid-19 melalui Pelatihan Personal Financial Health Check Up dengan tetap berupaya mempertahankan penjualan produk, sambil menggali informasi tentang kendala yang dihadapi pelaku UMKM pada masa pandemi Covid-19 dan memberikan kesempatan pada UMKM binaan Kadin Jawa Barat untuk menyampaikan harapan kepada pemerintah daerah pusat dan pemerintah pusat dalam upaya bangkit setelah adanya pandemi Covid-19.

\section{HASIL DAN PEMBAHASAN}

Perkembangan kasus konfirmasi positif COVID-19 di Indonesia per harinya semakin mengalami kenaikan yang signifikan. Pada tingkat nasional, data yang diperoleh dari website resmi perkembangan virus COVID-19 milik pemerintah pusat menyatakan sampai pada tanggal 17 April 2020 jumlah akumulasi kasus terkonfirmasi virus COVID-19 di Indonesia telah mencapai 83,130 kasus. Sejalan dengan semakin tingginya jumlah akumulasi kasus positif, kasus konfirmasi positif per harinya juga terus mengalami kenaikan.

Data menunjukkan bahwa pada tanggal 15 April di Indonesia terjadi1. 522 kasus dan pada 16 April naik secara signifikan menjadi 1.574 kasus (Gugus Tugas Percepatan Penanganan COVID-19, diakses pada tanggal 17 April 2020), Sedangkan jika dilihat pada tingkat regional, kasus konfirmasi positif paling banyak terjadi di Pulau Jawa. Hal ini terlihat dari peta penyebaran COVID-19 di provinsi-provinsi yang terletak di pulau Jawa menjadi daerah yang termasuk dalam 10 provinsi dengan jumlah kasus positif COVID-19 tertinggi di Indonesia. Pemerintah sudah mengeluarkan berbagai kebijakan fiskal maupun non fiskal untuk membantu masyarakat, perusahaan korporasi maupun UMKM yang terkena dampak pandemi Covid-19. Namun anggaran yang dimiliki oleh pemerintah sangat terbatas, sementara jumlah yang terpapar Covid-19 semakin hari semakin meningkat.

Oleh karena itu, permasalahan dan korban pandemi Covid-19 ini sangat memerlukan keterlibatan masyarakat, lembaga pendidikan tinggi maupun lembaga non bank lainnya. Contoh kolaborasi, misalnya UKM-UKM di Indonesia tidak berkembang dengan baik, karena terbatasnya akses keuangan (Yoshino dan Taghizadeh-Hesary, 2016). Selain itu, UMKM masuk dalam kelompok higher risk 
borrower (Zairani \& Zaimah, 2013) dan mempunyai jumlah kredit macet lebih tinggi dibanding Non-UMKM (Mutamimah \& Hendar, 2017).

Terbatasnya akses keuangan terjadi karena UMKM bisa mengakses modal ke lembaga keuangan konvensional karena UMKM tidak mempunyai laporan keuangan yang standard dan tingkat financial literacy nya rendah. Rendahnya financial literacy ini memerlukan lembaga pendidikan tinggi untuk memberikan pelatihan keuangan, sehingga para pelaku UMKM mempunyai kompetensi keuangan yang bagus, dan meningkatkan kepercayaan dari perbankan atau lembaga keuangan lain jika ingin mengakses kredit. Pandemi Covid-19 akan segera berakhir dan New Normal Economy akan mewujudkan gerakan ekonomi yang dapat meningkatkan pertumbuhan ekonomi, jika permasalahan diselesaikan secara kolaborasi sebagaimana Qur'an Surat AlMaidah ayat 2 dan QS Ar Ra'du ayat 11 . Pandemi covid-19 menjadi hikmah "Bangkitnya kembali Tatanan Ekonomi Baru" yaitu Sistem Ekonomi Islam yang selama ini berjalan perlahan yang tentunya menjadi kekuatan serta pemantik untuk mengurangi pengangguran, mengurangi kemiskinan serta meningkatkan kesejahteraan masyarakat. Manfaat Pemeriksaan finansial (financial check up):

1. Mengetahui pengeluaran secara detail. Pernahkah merasa gaji cepat habis? Misalnya, pada saat gajian pada tanggal 1 setiap bulannya. Kemudian, di tengah bulan sudah kehabisan uang. Dengan melakukan financial check up, kita bisa me-review kembali pengeluaranpengeluaran terbesar selama satu tahun belakangan. Selain itu, bisa juga mengingat kembali, apakah kita justru banyak mengeluarkan uang untuk membeli hal-hal yang tidak digunakan?

2. Mengontrol pengeluaran. Setelah mengetahui pengeluaran selama setahun belakangan, kita bisa membuat komitmen dengan diri sendiri untuk lebih hemat. Kita bisa menahan diri untuk membeli berbagai hal yang sudah terlalu banyak dibeli setahun kemarin.

3. Mempersiapkan keuangan masa depan. Ada baiknya kita merencanakan keuangan di masa depan. Apakah berencana untuk menikah, punya anak, membeli rumah, atau mobil? Jika iya, rencana tersebut bisa menjadi bagian dari perencanaan keuangan.

Hitung kebutuhan uang di masa depan. Kemudian, berdasarkan hasil pemeriksaan keuangan, tentukan cara terbaik untuk mencapai tujuan tersebut

\section{PENUTUP}

Pandemi Covid-19 telah memberikan dampak yang luas bagi perekonomian, tidak hanya di skala nasional tetapi juga di lingkup terkecil yakni keluarga.

Apalagi saat ini tak sedikit yang pendapatannnya berkurang bahkan harus kehilangan mata pencaharian sehingga pengaturan keuangan yang tepat menjadi hal penting yang harus dilakukan.

Agar Keuangan Keluarga Tetap Aman Di Masa Pandemi, Emiralda Noviarti mengatakan ada 5 hal yang perlu dilakukan untuk mampu menjadi pahlawan financial dalam keluarga di tengah resesi yang terjadi saat ini akibat pandemi Covid-19.

1. Proteksi Pintu PenghasilanProteksi pintu penghasilan utama yaitu dengan menganalisa kondisi tempat bekerja dan mencari cara menjadi solusi agar bisnis dapat tetap berjalan sehingga jika terjadi masalah dalam penghasilan bisa segera diatasi.

2. Atur Ulang Budget Bulanan. Mengatur ulang budget bulanan yang dilakukan dengan membagi pengeluaran dalam 5 pos utama yaitu cicilan, rutin, menabung atau investasi, sosial, dan lifestyle.

3. Siapkan Dana Darurat Memiliki dana darurat yang mencukupi. Menurutnya masyarakat harus menyadari pentingnya dana darurat di tengah kondisi yang penuh dengan ketidakpastian ini. Dana darurat untuk yang masih lajang dan belum memiliki tanggugan biasanya 4 kali lipat dari biaya pengeluaran, sedangkan untuk yang sudah berkeluarga bisa hingga mencapai 12 kali lipat dari kebutuhan setiap bulan.

4. Proteksi. Miliki proteksi dengan asuransi utama seperti asuransi kesehatan dan asuransi jiwa.

5. Investasi. Review rencana dan performa investasi sesuai dengan tujuan finansial. Pahami instrumen investasi dan faktor 
risikonya agar bisa membantu tercapainya tujuan finansial dalam rentang waktu yang sudah ditentukan sebelumnya.

Kegiatan pengabdian masyarakat yang telah kami laksanakan pada Kamis tanggal 25 Februari 2021 atas kerjasama antara Dosen Fakultas Ekonomi dan Bisnis Universitas Widyatama dengan Kadin Jawa Barat.keluarga.

\section{DAFTAR PUSTAKA}

Amri, Andi. (2020). Dampak COVID-19 terhadap UMKM di Indonesia. Jurnal BRAND, 2(1), 123-130.

Badan Pusat Statistik. (2008). Pertumbuhan Ekonomi Indonesia Triwulan I-2020 No. 39/05/Th. XXIII. Jakarta: Badan Pusat Statistik.

Elisa M. Maffioli, 2020, How is the World Responding to the 2019 Coronavirus Disease Compared with the 2014 West African Ebola Epidemic? The Importance of China as a Player in the Global Economy, Am. J. Trop. Med. Hyg., $\quad 00(0), \quad$ pp. $1-2$ doi:10.4269/ajtmh.20-0135

Hadiwardoyo, W. (2020). Kerugian Ekonomi Nasional Akibat Pandemi Covid-19. Baskara Journal of Business and Enterpreneurship, 2(2), 83-92. https://doi.org/10.24853/baskara.2.2. 83-92

Haque, MG., Munawaroh, Sunarsi, D., (2020). Analysis of SMEs Culinary Marketing Strategy During Covid 19 Pancemic: A Study at "Sate Bebek Cilegon" Resto in Cilegon, Banten. International Journal of Education, Information Technology, and Others. Vol.3. Issue 2

Khan, N., Faisal, S. 2020, Epidemiology of Corona Virus in the World And Its Effects on The China Economy,
Electronic copy available at: https://ssrn.com/abstract=3548292, diakses 26 maret 2020

Kementerian Koperasi dan Usaha Kecil dan Menengah Republik Indonesia. (2018). Perkembangan Data Usaha Mikro, Kecil, Menengah (UMKM) dan Usaha Besar (UB) Tahun 2017-2018.

Maijamaa, B., Nweze, N. O., \& Bagudu, H. D. (2020). Coronavirus Disease (Covid19), is Global Recession Evitable?. Jurnal Aplikasi Manajemen, Ekonomi dan Bisnis, 4(2), 71-77.

McKibbin, W. J., \& Vines, D. (2020). Global macroeconomic cooperation in response to the COVID-19 pandemic: a roadmap for the G20 and the IMF. Forthcoming in 'The Economics of the COVID-19 Pandemic, 36.

Mckibbin, Warwick, and Roshen Fernando. "The Global Macroeconomic Impacts of COVID- 19: Seven Scenarios *." CAMA Working Paper No.19/2020 (2020).

Sutrisno, S., Abidin, A. Z., Winata, H., Harjianto, P., \& Sunarsi, D. (2020). Penyuluhan Pengelolaan Keuangan Sederhana Siswa SMA 6 Tangerang Selatan. BAKTIMAS: Jurnal Pengabdian pada Masyarakat, 2(1), 67-71.

Yoshino, Naoyuki; Wignaraja, Ganeshan. (2015). SMEs Internationaliztion and Finance in Asia. Tokyo: ADB Institute. Diunduh pada 09 Oktober 2016. Tersedia pada https://www.imf.org

Zairani, Z., \& Zaimah, Z. A. (2013)," Difficulties in Securing Funding from Banks : Success Factors for Small and Medium Enterprises ( SMEs )", 1(4), 354-357.

https://doi.org/10.12720/joams.1.4.3 54-357 